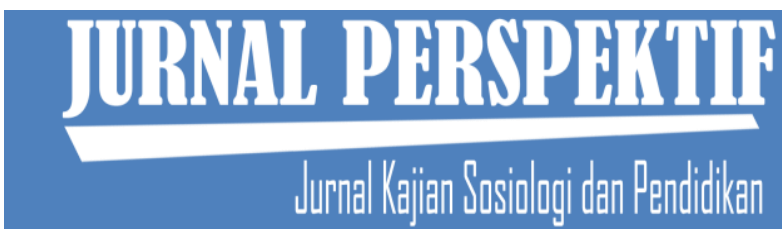

Jurnal Perspektif: Jurnal Kajian Sosiologi dan Pendidikan Vol. 3 No. 4 Tahun 2020

http://perspektif.ppj.unp.ac.id

Email: perspektif@ppj.unp.ac.id

ISSN: 2622-1748 (Online), 2684-902X (Print)

DOI: http://dx.doi.org/10.24036/perspektif.v3i4.377

\title{
Fungsi Pernikahan Dini Bagi Remaja di Kelurahan Gurun Laweh Nan XX Kecamatan Lubuk Begalung Kota Padang
}

\author{
Indah Indah', Desy Mardhiah ${ }^{2}$ \\ 1,2 Universitas Negeri Padang \\ Email: 05indah1996@gmail.com, desy_padang@yahoo.com
}

\begin{abstract}
Abstrak
Pernikahan dini memiliki resiko \& dampak yang tinggi. Pemerintah melalui UU Perkawinan mengatur batasan usia minimal melakukan pernikahan untuk meminimalisir terjadinya pernikahan dini . Namun, realita dilapangan Indonesia menduduki peringkat ke 2 se Asia Tenggara remajanya yang banyak melakukan pernikahan dini. Kecamatan Lubuk Begalung Kota Padang tercatat memiliki angka pernikahan dini yang tinggi. Fenomena di lapangan juga memperlihatkan dominasi pernikahan dini yang dilakukan secara sirri oleh remaja Kelurahan Gurun Laweh Kecamatan Lubuk Begalung tinggi. Penelitian ini betujuan untuk menjelaskan apa saja fungsi pernikahan dini bagi remaja. Teori yang digunakan untuk menganalisis penelitian ini adalah teori Robert K. Merton yaitu fungsional stuktural . Metode yang digunakan dalam penelitian ini adalah metode penelitian kualitatif dengan tipe studi kasus serta teknik pemilihan informan secara snowball sampling. Dalam pengumpulan data dilakukan dengan cara observasi, wawancara, dokumentasi dengan teknik analisis data dari Miles dan Huberman . Hasil penelitian ini menjelaskan fungsi manifest yaitu fungsi yang diharapkan remaja yang melakukan pernikahan dini adalah (1). Kebutuhan akan rasa aman. (2). Kebutuhan akan cinta dan kasih sayang. (3). Mengubah kondisi ekonomi menjadi lebih baik. Serta fungsi latent yaitu fungsi yang tidak diaharapkan oleh remaja yang melakukan pernikahan dini adalah (1). Menutupi aib keluarga. (2). Mencegah timbulnya fitnah.
\end{abstract}

Kata Kunci : Fungsi Pernikahan Dini, Kelurahan Gurun Laweh Nan XX, Kecamatan Lubuk Begalung, Remaja yang menikah dini

\section{Abstract}

Early marriage has a high risk \& impact. The Government through the Marriage Law regulates the minimum age limit for marriage to minimize the occurrence of early marriage. However, the reality in the Indonesian field is ranked 2nd in Southeast Asia where teenagers have a lot of early marriage. Lubuk Begalung Subdistrict, Padang City is recorded has a high rate of early marriage. The phenomenon in the field also shows the dominance of early marriage which is carried out by teenagers in Gurun Laweh Village, Lubuk Begalung District. This research aims to explain what are the functions oearly marriage for adolescents. The theory used to analyze this research is Robert K. Merton's theory is structural functional. The method used in this research is a qualitative research method with the type of case study and the technique of selecting informants by snowball sampling. Data collection is carried out by means of observation, interviews, documentation with data analysis techniques from Miles and Huberman. The results of this study explain that the function of the manifest is a function. what is expected by adolescents who carry out early marriages are (1). The need for security. (2). The need for love and affection (3). Changing economic conditions for the better. As well as the latent function, which is a function that is not expected by adolescents who carry out early marriages, namely (1). Covering the disgrace of the family. (2). Prevent slander.

Keywords: Function of Early Marriage, Teens who marry early, Gurun Laweh Nan XX Village, Lubuk Begalung District.

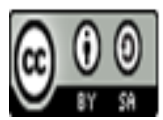

Received: November 9, $2020 \quad$ Revised: November 29, 2020 Available Online: November 30, 2020 


\section{Pendahuluan}

Pernikahan adalah suatu hal yang sakral dimana terjadi ikatan suci dan resmi antara lakilaki dengan perempuan. Pernikahan adalah penyatuan dua insan untuk saling mencintai dan mengasihi. Dibutukan kesiapan yang matang dari kedua belah pihak dalam menjalankan pernikahan. Pernikahan dini adalah pernikahan yang terjadi pada usia remaja atau pernikahan yang terjadi antara laki-laki dan perempuan sebelum batas umur yang tepat atau ideal untuk melakukan pernikahan (Romauli \& Vindari, 2012). Hal ini dikarenakan remaja belum memiliki kematangan baik dalam segi fisik, psikologis, maupun emosional. (Monks, F.J., Knoers \& S.R, 2002) membatasi masa remaja yang berkisar dari usia 12 sampai 21 tahun yakni sampai selesainya pertumbuhan fisik. Menurut (Santrcok \& W, 2002) menjelaskan"adolescence is a time of "strom and stress". Artinya, remaja adalah masa yang penuh dengan "badai dan tekanan jiwa", yaitu masa di mana terjadi perubahan besar secara fisik, intelektual dan emosional pada seseorang yang menyebabkan kesedihan dan kebimbangan (konflik) pada yang bersangkutan, serta menimbulkan konflik dengan lingkungannya.

Menurut WHO (Wo rld Health Organizations), remaja putri yang menikah usia 15-19 tahun biasanya tidak mampu untuk bernegosiasi dengan suami, mengambil keputusan dalam keluarga dan melindungi kesehatan mental mereka. Ada kolerasi yang kuat antara pernikahan dini dengan perceraian (Ani \& Endah, 2019). Bahkan dalam penelitian (Robert \& B, 2002) menjelaskan bahwa pernikahan di usia dini mengalami tingkat perceraian yang cukup tinggi. Jumlah perceraian pria yang menikah di usia remaja menjadi tiga kali lipat dari pada tingkat perceraian pria yang menikah di usia dua puluh tahun ke atas. Persoalan perkawinan di Indonesia sebelumnya diatur dalam UU No.1 Tahun 1974, yang menjelaskan mengenai batasan usia perkawinan antara laki-laki dan perempuan yaitu laki-laki hanya diizinkan menikah apabila telah berusia 19 Tahun dan 16 Tahun pada perempuan. Pada tahun 2019 UU perkawinan tersebut mengalami perubahan pada batasan usia perkawinan. Perubahan yang ditetapkan menjelaskan, bahwa usia perkawinan antara laki-laki dan perempuan hanya diizinkan pada umur 19 Tahun.Sebagaimana dimuat dalam pasal 7 ayat 1 UU No. 16 Tahun 2019. Kota Padang adalah salah satu wilayah yang juga masih cenderung ditemukan pernikahan usia dini.

Tabel. 1. Pelaksanaan Nikah di Kota Padang Menurut Usia Tahun 2015

\begin{tabular}{|c|c|c|c|c|c|c|c|c|}
\hline \multirow{2}{*}{ No } & \multirow{2}{*}{ Kecamatan } & \multicolumn{6}{|c|}{ Umur } & \multirow{2}{*}{ Jumlah } \\
\hline & & $\overline{L k}$ & $\operatorname{Pr}$ & $\mathrm{Lk}$ & $\operatorname{Pr}$ & $\mathrm{Lk}$ & $\operatorname{Pr}$ & \\
\hline 1 & Padang Barat & 152 & 54 & 57 & 165 & 143 & 76 & 647 \\
\hline 2 & Padang Timur & 188 & 91 & 339 & 325 & 401 & 273 & 617 \\
\hline 3 & Padang Utara & 107 & 61 & 78 & 136 & 265 & 175 & 823 \\
\hline 4 & Padang Selatan & 147 & 54 & 123 & 165 & 251 & 189 & 929 \\
\hline 5 & Pauh & 109 & 32 & 143 & 201 & 276 & 152 & 913 \\
\hline 6 & Kuranji & 308 & 107 & 417 & 411 & 735 & 523 & 2501 \\
\hline 7 & Lubuk Kilangan & 129 & 96 & 65 & 102 & 209 & 140 & 741 \\
\hline 8 & Lubuk Begalung & 376 & 168 & 164 & 269 & 396 & 325 & 1698 \\
\hline 9 & Bungus TL Kabung & 51 & 39 & 45 & 58 & 125 & 79 & 407 \\
\hline 10 & Koto Tangah & 578 & 581 & 578 & 581 & 949 & 465 & 3161 \\
\hline 11 & Nanggalo & 129 & 139 & 103 & 139 & 253 & 153 & 916 \\
\hline 12 & Jumlah & 1917 & 2552 & 1170 & 2552 & 4003 & 2550 & 14353 \\
\hline
\end{tabular}

Sumber: Kantor Kemenag Kota Padang, 2016. 
Dari data diatas memperlihatkan dominasi remaja yang menikah dini di Kecamatan Lubuk Begalung cenderung tinggi. Dimana Kecamatan Lubuk Begalung menempati posisi ke 2 remajanya, yang banyak melakukan pernikahan dini. Sedangkan jika dibandingkan dengan data jumlah penduduk pada Tahun yang sama, Kecamatan Lubuk Begalung menempati posisi ke 3 penduduk terbanyak di Kota Padang.

Tabel 2. Data Penduduk Menurut Kecamatan

\begin{tabular}{llll}
\hline \multicolumn{1}{c}{ Kecamatan } & \multicolumn{1}{c}{ Laki-laki } & \multicolumn{1}{c}{ Perempuan } & Total \\
\hline Bungus TL Kabung & 12.559 & 11.849 & 24.408 \\
\hline Lubuk Kilangan & 27.025 & 26.626 & 53.651 \\
\hline Koto Tangah & 91.928 & 90.368 & 182.296 \\
\hline Kuranji & 70.288 & 71.055 & 141.343 \\
\hline Lubuk Begalung & 59.314 & 58.007 & 117.321 \\
\hline Nanggalo & 29.222 & 30.935 & 60.157 \\
\hline Padang Barat & 23.167 & 22.740 & 45.907 \\
\hline Padang Selatan & 29.747 & 29.540 & 59.287 \\
\hline Padang Timur & 39.354 & 39.797 & 79.151 \\
\hline Padang Utara & 33.417 & 37.027 & 69.119 \\
\hline Pauh & 34.557 & 33.891 & 59.216 \\
\hline
\end{tabular}

\section{Sumber: Badan Pusat Statistik Kota Padang.}

Fenomena dilapangan, banyak ditemukan pernikahan dini di Kelurahan Gurun Laweh Kecamatan Lubuk Begalung adalah melalui pernikahan sirri. Pernikahan sirri adalah pernikahan rahasia yang dilakukan tanpa melapor ke Kantor Urusan Agama. Hal tersebut tentu merungikan remaja, karena pernikahan tersebut tidak dapat dilindungi oleh azas - azas peraturan negara. Seperti yang tertera dalam UU No.1 tahun 1974 tentang perkawinan tertulis pada Bab I dasar perkawinan pasal 2 ayat 2 : Tiap - tiap perkawinan dicatat menurut peraturan perudang - undangan yang berlaku. Serta tertera dalam KHI (Kompilasi Hukum Indonesia) Bab II, Pasal 5 menyebutkan: Agar terjamin ketertiban perkawinan bagi masyarakat Islam, setiap perkawinan harus dicatatkan. Dan ditegaskan dalam pasal 6: Perkawinan yang dilakukan di luar pengawasan pegawai pencatat nikah tidak mempunyai kekuatan hukum.

Salah satu kasus yang dtemukan di Kelurahan Gurun Laweh Nan XX Kecamatan Lubuk Begalung Padang, ditemukannya 1 keluarga memiliki 4 orang anak dan keseluruh anaknya tersebut melakukan pernikahan dini dibawah tangan (nikah sirri). Fenemena lain pernikahan dini yang juga ditemukan di Kelurahan Gurun Laweh Kecamatan Lubuk Begalung yaitu pernikahan dini dengan merebut suami orang (pelakor). Yang sangat disesali yaitu sang pelakor masih berusia 15 tahun.Kasus lainnya yang ditemukkan akhir tahun 2019 yaitu remaja laki-laki melakukan pernikahan dini dibawah tangan dan berakhir pada putusnya tali pendidikan. Pada tahun yang sama akhir 2019 ditemukan seorang remaja berusia 13 tahun hamil muda dan menikah dibawah tangan. Umur 13 tahun adalah umur yang masih sangat dini untuk terjadinya sebuah kehamilan. Dimana masa seorang anak baru beranjak ke remaja awal.

Penelitian Siti Nurjannah, Yohannis Franz La Khahija yang berjudul Pengalaman Wanita Menikah Dini Yang Berakhir dengan Perceraian. Fokus Penelitian ini adalah apa yang membuat remaja yang menikah dini bercerai (Nurjannah \& Khahijah, 2018) . Penelitian Intan Arimurti, Ira Nurmala yang berjudul Analisi Pengetahuan Perempuan Terhadap Perilaku Melakukan Pernikahan Usia Dini Di Kecamatan Wonosari Kabupaten Bondowono 
menyimpulkan bahwa perempuan yang menikah dibawah usia 18 tahun pendidikan yang ditempuh baik informan kunci maupun informan pendukung adalah SD dan SMP. Kontribusi yang berpengaruh dalam pernikahan usia dini pada penelitian ini yaitu rendahnya pengetahuan yang dimiliki oleh informan kunci dan informan pendukung.Hal yang berkaitan dengan informan adalah rendahnya pengetahuan pada lingkungan terhadap pernikahan usia dini, rendahnya pemanfaatan media massa, pengalaman pada orang tua, keluarga maupun lingkungan hal tersebut menjadikan perilaku pernikahan dini biasa dilakukan. Pengetahuan yang rendah yang dimiliki oleh informan terhadap dampak kesehatan yang dirasakan setelah menikah di usia dini menjadikan masyarakat terus-menerus melakukan kebiasaan menikah pada usia dini. (Arimurti \& Nurmala, 2017). Penelitian Nazli Halawani Pohan yang berjudul Faktor yang berhubungan dengan pernikahan usia dini terhadap remaja putri tentang gambaran faktor yang berhubungan dengan pernikahan usia dini terhadap remaja putri. Hasil penelitian ini menunjukkan bahwa ada hubungan antara pengetahuan, pendidikan, pekerjaan, status ekonomi, budaya, pergaulan bebas dan media massa dengan pernikahan usia dini pada remaja putri. Serta tidak ada hubungan antara peran orang tua dengan pernikahan usia dini pada remaja putri. Faktor yang paling dominan yang berhubungan dengan pernikahan usia dini pada remaja putri adalah pengetahuan (Putri, 2017). Penelitian Uswatun Hasanah yang berjudul Pengaruh Perkawinan Usia Muda Pada Tingkat Perceraian Dini (Studi kasus Pengadilan Agama Kisaran). Penelitian ini dilatarbelakangi oleh perceraian akibat pernikahan dini selalu meningkat. Hasil dari penelitian ini adalah perkawinan usia muda dilakukan oleh seseorang yang pada hakekatnya kurang mempunyai persiapan atau kematangan baik secara biologis, psikologis maupun sosial ekonomi. Faktor penyebab perceraian dini pada perkawinan usia muda adalah krisis moral dan akhlak, status sosial ekonomi, dan usia saat menikah (Uswatun, 2018).

\section{Metode Penelitian}

Penelitian fungsi remaja menikah dini di Kelurahan Gurun Laweh Nan XX Kecamatan Lubuk Begalung Padang adalah karena pernikahan dini yang terjadi di Kelurahan Gurun Laweh Nan XX Kecamatan Lubuk Begalung cenderung tinggi dan didominasi oleh pernikahan dini yang dilakukan secara sirri ( rahasia) yang tidak dapat dilindungi secara hukum negara karena tidak melapor ke Kantor Urusan Agama. Dalam penelitian kualitatif ini data dan informan ditelusuri seluas - luasnya dan sedalam mungkin sesuai dengan variasi yang ada, sehingga dengan cara demikian peneliti mampu menjelaskan fenomena secara utuh(Bugin, 2010). Tipe penelitian yang diajukan oleh peneliti adalah studi kasus.Penelitian studi kasus ini bertujuan secara khusus untuk menjelaskan serta memahami objek yang diteliti secara khusus sebagai suatu kasus dan menjelaskan bagaimana keberadaan serta mengapa kasus tersebut terjadi.Pemilihan informan dilakukan dengan menggunakan teknik - teknik tertentu tujuannya untuk menjaring sebanyak mungkin informan yang akan menjadi dasar dari rancangan dan teori yang akan dibangun, maka dari itu teknik pemilihan informan dilakukan secara sowball sampling, yang menjadi informan kunci peneliti disini adalah OL yang merupakan remaja yang melakukan pernikahan dini dan informan lainnya yang berinisial SV, PJ, HN, GL, PJ, ND, YN,MS, FN, SH, Agnes, Mawar, Nurhayani.

Observasi dilakukan dengan mengumpulkan data dengan mengambil secara langsung data dari masyarakat yang menjadi objek yang akan diteliti. Di dalam penelitian yang diamati ini, peneliti meneliti tentang fungsi manifest dan fungsi latent remaja melakukan pernikahan dini di Kelurahan Gurun Laweh Nan XX Kecamatan Lubuk Begalung Padang. Hal yang dilakukan untuk memperoleh data yang didpatkan dari hasil wawancara dan studi dokumentasi. 
Dalam hal ini peneliti secara langsung mengamati informan utama yaitu remaja yang melakukan pernikahan dini. Setelah mengamati bagaimana aktifitas yang terjadi di lokasi penelitian. Peneliti melakukan wawancara dengan subjek peneliti yaitu remaja, keluarga dan teman remaja. Wawancara yang peneliti lakukan adalah wawancara mendalam merupakan tekik pengumpulan data yang didasarkanpada percakapan secara intensif dengan menggunakan pedoman wawancara atau catatan yang berisikan pemikiran yang merupakan pertanyaan mendalam yang akan ditanyakan pada saat wawancara langsung (Sugiyono., 2016). Melalui awancara mendalam secara tatap muka, maka peneliti akan mendapatkan data mengenai permasalahan yang ingin diteliti oleh wawancara serta membuat pertanyaa $5 \mathrm{~W}+1 \mathrm{H}$ yang akan dikembangkan saat wawancara berlangsung. Hal ini bertujuan agar peneliti memperoleh data yang dibutuhkan.

Agar data yang peneliti peroleh dalam penelitian akurat, valid dan sah, maka dilakukan dengan teknik triangulasi data.Triangulasi data adalah teknik pemeriksaan keabsa han data dengan memamfaatkan sesuatu yang berda diluar data tersebut. Data yang sama dikumpulan dari objek yang dibutuhkan(Bagong, 2011). Hal ini bertujuan untuk pengecekan atau pembanding terhadap data yang sudah diperoleh peneliti. Teknik analisis menggunakan teknik analisis data Miles dan Huberman.

\section{Hasil dan Pembahasan}

Dari hasil penelitian ditemukan Pernikahan Dini Di Kelurahan Gurun Laweh Nan XX Kecamatan Lubuk Begalung Padang di dasari oleh fungsi manifest dan fungsi latent sebagai berikut:

\section{Fungsi Manifest Remaja Menikah Dini (Fungsi Yang Diharapkan/Nyata)}

\section{Kebutuhan akan rasa aman}

Kebutuhan akan rasa aman, dalam konsep teori Hierarki oleh Abraham Maslow dimana, pemenuhan kebutuhan dasar manusia dibagi menjadi suatu tingkatan tertentu yang memprioritaskan kebutuhan manusia dari yang paling dasar ke tingkat yang lebih tinggi, hal tersebut yang menjadi motivasi. Kebutuhan rasa aman adalah kebutuhan nomor 2 paling dasar yang harus dipenuhi manusia, meliputi kebutuhan rasa aman fisik, perlindungan, kebebasan dari ancaman, ketergantungan dan perlindungan ( www.wikipedia.com ). Remaja pada masa yang penuh gejolak membutuhkan rasa aman yang intens. Dari kejenuhan data ditemukan remaja yang menikah dini dikarenakan kebutuhan mereka akan rasa aman. Salah satu informan remaja yang menikah dini berinisial SV yang merupakan teman remaja Agnes yang juga menikah dini menceritakan awal mula hingga terjadinya pernikahan dininya. Pada waktu dilakukan wanwancara SV menjawab pertanyaan dengan bahasa yang mudah dipahami dan menceritakannya secara detail.

“...Ayah saya seorang narapidana dan ibu saya berjual kecil - kecilan. Setiap saya memiliki masalah saya berusaha berbagi ke ibu saya. Namun, jawaban yang saya terima, malah sebuah kekecewaan. Pernah suatu waktu saya ingin pergi sekolah, saya meminta uang jajan. Namun, hujatan yang saya terima dari ibu saya walaupun setelah itu dia memberikan. Saya berusaha untuk tidak melawan dan pergi. Di sekolah saya punya pacar yaitu suami saya yang dulu sering duduk sebangku dengan saya. Segala permasalahan saya ceritakan padanya. Kami semakin sering bersama. Saya juga sudah sangat nyaman..." (Wawancara pada tanggal 12 Juli 2020 dalam bahasa Indonesia). 
Informan lain yang baru saja melahirkan seorang bayi pada bulan juli 2020, seorang remaja yang masih berusia 15 tahun sudah menimang bayi pada saat peneliti mengunjungi rumah remaja. Remaja dengan ramah dan sedikit malu berbicara mengenai pernikahannya. Dengan bahasa yang mudah dipahami informan menjelaskan: PJ inisial remaja yang melakukan pernikahan dini secara sirri :

“...Kami berdua menikah pada bulan february 2020 waktu itu kehamilan saya sudah bulan. Awalnya saya berniat untuk menggugurkan kandungan. Namun, saya tetap tidak tega terhadap janin yang berada di dalam rahim saya dan takut. Saya akhirnya memutuskan menikah dini secara sirri..." (Wawancara pada tanggal 24 Juli 2020 dalam bahasa Indonesia).

Informan lain seorang remaja yang baru saja melahirkan bayinya pada akhir 2019 . Namun, sang bayi meninggal dunia pada karena kondisi bayi yang sangat lemah. Informan Remaja berisinial HN yang melakukan pernikahan dini secara sirri menjelaskan sambil menangis:

“...Saya bekerja paruh waktu dan setiap saya pulang kerja selalu bertemu dengan suami di jalan dekat kerumah saya. Suami saya sering nongkrong di daerah sekitar rumah saya. Karena sering bertemu suami saya mengajak saya berpacaran, beberapa bulan pacaran saya hamil. Agar merasa tenang dan aman saya bersama suami memutuskan menikah dini secara sirri. Akhirnya kami menikah secara sirri. Namun, bayi saya meninggal pada saat berumur 15 hari. Hal tersebut masih membuat saya sedih. Saya terkadang sering ribut dengan suami saran pun berdatangan untuk menyudahi pernikahan saya. Namun, saya masih memiliki tekad untuk menjaga dan melindungi keluarga kecil kami sampai memiliki anak cucu..." (Wawancara peneliti lakukan pada tanggal 22 Juli 2020 dalam bahasa Indonesia).

Dapat dilihat dari apa yang telah disampaikan oleh informan salah satu fungsi dari remaja melakukan pernikahan dini adalah kebutuhan akan rasa aman. Kebutuhan rasa aman adalah konsekuensi yang didasari untuk menciptakan adaptasi dan penyesuaian. Kebutuhan rasa aman meliputi perlindungan, ketergantungan dengan orang lain, stabilitas, kebebasan dari ancaman dan bahaya.

\section{Kebutuhan akan cinta dan kasih sayang}

Cinta itu buta adalah suatu istilah yang pantas diberikan kepada insan yang sedang jatuh cinta. Tidak terkecuali para remaja, dari beberapa kasus yang ditemukan remaja yang jatuh cinta rela melakukan apapun demi pasangannya. Hal tersebut ia lakukan dengan sukarela dan senang hati. Jatuh cinta adalah suatu kebahagiaan yang tiada tara membuat remaja ingin melakukan pernikahan di usia yang dini. Salah satu narasumber seorang remaja yang menikah dini yaitu beranisial ND mengatakan:

“...Kami saling sayang saya juga melihat keseriusan sang suami serta perhatiannya. Dari pada kami berpacaran terus dan malah menimbulkan fitnah akhirnya kami menghalalkan hubungan kami dengan menikah sirri..." (Wawancara pada tanggal 24 Juli 2020 dalam bahasa Indonesia).

Informan lain juga sependapat, dalam waktu yang berbeda saat peneliti wawancara juga mengatakan hal yang sama yaitu informan YN yang baru saja melangsungkan pernikahan dini secara sirri menjelaskan: 
“....Kami saling sayang dan kami ingin menghalalkan hubungan kami.Saling sayang adalah alasan kuat kami memutuskan menikah daripada terus - terusan berpacaran yang tidak tentu arah dan nanti menimbulkan hal yang tidak diinginkan...." (Wawancara pada tanggal 25 Juli 2020 dalam bahasa Indonesia).

Informan selanjutnya teman remaja yang melakukan pernikahan dini bernama Agnes menjelaskan :

“...Cinta itu buta, remaja kalau sedang khasmaran itu apa saja akan dilakukan. Kadang mereka tidak memikirkan dampak dari hubungan yang mereka lakukan sebelum menikah. Ada juga yang daripada pacaran terus yang dapat menimbulkan aib, teman saya memilih untuk menikah, walaupun harus dilakukan secara sirri..."(Wawancara pada tanggal 11 Juli 2020 dalam bahasa Indonesia).

Informan ibu remaja yang anaknya menikah dini secara sirri bernama Mawar mengatakan :

"...Anak saya sibuk pacaran taruih. Kadang pulang malam jam sapuluah malam. Saya orang tua tentu melarang. Namun, anak alah gadang kita urang gaek menasehati ndak takao acok - acok mamberangan. Nyo minta nikah. Awak gaeknyo tu setuju se lai daripado nyo pacaran taruih ndak tantu arah. Biko zina alun lai malunyo..." (Wawancara pada tanggal 21 Juli 2020 dalam bahasa Indonesia). Terjemahan :

“...Anak saya sibuk pacaran terus. Kadang pulang jam sepuluh malam. Saya orang tua tentu melarang. Namun, anak sudah besar kita orang tua tidak sanggup memarahi terus - menerus. Dia minta izin nikah. Kita orang tua lebih memilih setuju daripada dia pacaran terus tidak tentu arah.Yang nantinya bisa menimbulkan zina dan membuat malu keluarga..."(Wawancara pada tanggal 21 Juli 2020 dalam bahasa Indonesia).

Dapat dilihat dari apa yang telah disampaikan oleh informan salah satu fungsi dari remaja melakukan pernikahan dini adalah kebutuhan akan cinta dan kasih sayang. Konsekuensi tersebut mendorong remaja untuk melakukan pernikahan dini.

\section{Mengubah kondisi ekonomi keluarga menjadi lebih baik}

Hidup dengan pas - pasan serta memutuskan untuk tidak sekolah lagi membuat sang remaja melakukan pernikahan dini. Dari salah satu narasumber yang berinisial MS remaja yang menikah dini dan sudah memiliki 3 anak dan anak sulungnya berusia 5 tahun. Sedangkan usianya baru menginjak 21 tahun berinisial MS menjawab pertanyaan peneliti dengan bahasa yang mudah dipahami.

“...Kehidupan ekonomi keluarga kami sudah susah saya akhirnya memutuskan untuk tidak sekolah lagi. Karena minat saya untuk melanjutkan pendidikan juga sudah tidak ada rasanya saya ingin membantu orang tua saja. Suatu hari saya bertemu dengan seorang pria yang sudah mengenal saya selama 1 tahun. Akhirnya ia bertemu dengan ibu saya dan meminta saya kepada ibu saya. Ibu saya pun setuju dan menjodohkan saya dengannya. Dengan suatu harapan yang ia berikan kepada saya dan ibu saya. Yaitu ia berjanji ingin mengubah keadaan ekonomi keluarga saya menjadi lebih baik..."(Wawancara pada tanggal 13 Juli 2020 dalam bahasa Indonesia).

Informan lain yang berinisial FN menceritakan pernikahan dininya dan sekarang ia tinggal bersama suami ke 4 nya dan memiliki 2 orang anak. FN yang merupakan saudaranya MS dan OL menjelaskan : 
“...Suami saya yang pertama berasal dari keluarga yang berada. Saat itu ia sangat serius dengan hubungan kami dan ingin mengubah nasib keluarga saya. Setelah menikah, dia pun menepati janji ( saat melamar saya ) yaitu mendirikan usaha warnet untuk ibu saya dan membelikan adik saya sepeda motor ( untuk mengojek). Di usia pernikahan saya yang ke 2, saya dan mantan suami memutuskan untuk bercerai. Saat ini saya tinggal bersama suami ke empat saya dan 2 orang anak kami..."(Wawancara pada tanggal 14 Juli 2020 dalam bahasa Indonesia)

Dapat dilihat dari apa yang telah disampaikan oleh informan salah satu fungsi dari remaja melakukan pernikahan dini adalah untuk mengubah kondisi ekonomi menjadi lebih baik. Keadaan yang serba kekurangan membuat remaja memutuskan melakukan pernikahan dini dengan tujuan agar dapat hidup lebih baik.

Fungsi laten remaja menikah dini ( fungsi tersembunyi / tidak diharapkan remaja).

\section{Menutupi aib keluarga}

Hasil wawancara peneliti menemukan pernikahan dini dilakukan remaja mempunyai fungsi tersembunyi. Yaitu remaja ingin menutupi aib keluarga. Kehamilan yang terjadi sebelum proses pernikahan dan untuk menutupi aib keluarga tersebut remaja melakukan pernikahan dini sebagai solusi. Menikah dini pun dilakukan remaja secara sirri seperti yang diungkapkan oleh remaja berinisial PJ yang menikah dini secara sirri:

“... Saya hamil 4 bulan membuat saya panik, usia saya baru saja menginjak15 tahun. Akhirnya saya menikah dengan suami saya secara sirri. Pernikahan sirri memang bukan keputusan yang baik. Namun, itu adalah satu jalan dan untuk menutupi aib keluarga..." (Wawancara pada tanggal 30 Juli 2020 dalam bahasa Indonesia).

Informan lainnya adalah penjual yakult keliling yang melakukan pernikahan dini dan menceritakan banyaknya keluarga, teman dan tetangga yang melakukan pernikahan dini, Ola menjelaskan:

"...Keluarga, lingkungan dan saudara memang banyak yang menikah dini. Kakak kandung saya dan saudara sepupu saya berempat orang bersaudara (semuanya) menikah dini secara sirri, karena hamil di luar nikah. Akhir tahun 2019 silam, ponakan saya GL juga menikah dini secara sirri karena hamil di luar nikah. Selama berjualan yakult keliling di daerah Gurun Laweh Kecamatan Lubuk Begalung saya banyak menemukan remaja yang menikah dini dan umumnya karena hamil diluar nikah. Baru - baru ini seorang remaja langganan yakult saya, yang berusia 13 tahun menikah dini karena hamil di luar nikah, terakhir kali pada saat saya mengantarkan yakult ke rumahnya, perutnya sudah semakin besar..." (Wawancara pada tanggal 4 Juli 2020 dalam bahasa Indonesia).

SH remaja yang menikah dini secara sirri membenarkan apa yang disampaikan oleh Ola

“...Saya menikah pada saat duduk dibangku kelas 3 SMP. Saya menikah dengan suami secara sirri. Saya berempat bersaudara kami semua menikah secara sirri. Awalnya abang saya yang berinisial IG menikah karena istrinya hamil diluar nikah..."( Wawancara pada tanggal 10 Juli 2020 dalam bahasa Indonesia).

Informan lainnya remaja berinisial Agnes yang menikah dini dan teman, tetangga nya juga melakukan pernikahan dini menjelaskan :

“...Teman saya yang pertama kali hamil diluar nikah adalah SV. Dan orang yang ia beri tahu adalah saya dan teman dekat kami. Akhirnya teman saya SV menikah secara sirri. Teman saya AY, D H dan IK juga sama menikah secara sirri karena 
sudah hamil duluan. Saya juga menikah dini, tetapi bukan karena hamil duluan. Saya memutuskan menikah karena daripada saya pacaran dan menimbulkan fitnah saya lebih memilih untuk menikah dini secara sirri. Rasanya saya malu apabila hamil diluar nikah dan menjadi pembicaraan masyarakat sekitar. Banyak juga yang kadang menggosipkan saya. Lebih baik saya mencegah timbulnya fitnah itu.Pernikahan saya ternyata hanya bertahan seumur jagung dengan mantan suami. Sekarang saya bekerja di salah satu kantor dan masih single..." ( Wawancara pada tanggal 8 Juli 2020 dalam bahasa Indonesia).

Dapat dilihat dari apa yang telah disampaikan oleh informan salah satu fungsi latent (tersembunyi) atau yang tidak diharapkan remaja yang melakukan pernikahan dini adalah untuk menutupi aib keluarga.

\section{Mencegah timbulnya fitnah}

Remaja yang selalu berpacaran tentu menjadi perbincangan hangat bagi masyarakat sekitar. Seperti yang diungkapkan oleh narasumber YN :

“...Kami sudah lama berpacaran, setiap kali kami pergi berdua tetangga selalu memperbincangkan kami. Hal itu membuat kami resah. Daripada kami

berpacaran teres menerus dan menimbulkan fitnah kami memilih menikah secara sirri...." (Wawancara pada tanggal 25 Juli 2020 dalam bahasa Indonesia).

Agnes remaja yang melakukan pernikahan dini dan banyaknya teman, tetangga yang melakukan pernikahan dini secara sirri menjelaskan.

"...Nah kalau teman saya disekolah banyak nikah dini karena daripada menimbulkan fitnah mereka lebih memilih untuk menikah dini secara sirri. Termasuk saya yang memilih menikah dini secara sirri...." (Wawancara pada tanggal 10 Juli 2020 dalam bahasa Indonesia).

Dapat dilihat dari apa yang telah disampaikan oleh informan salah satu fungsi laten (tersembunyi) atau tidak diharapkan remaja yang melakukan pernikahan dini adalah untuk mencegah timbulnya fitnah. Hidup dalam masyarakat sosial tentu tidak lepas dari omongan masyarakat. Untuk menghindari hal tersebut remaja memilih untuk melakukan pernikahan dini.

Teori Fungsional struktural yang dipopulerkan oleh Robert K. Merton menekankan kepada keteraturan (order) dan mengabaikan konflik dan perubahan - perubahan dalam masyarakat. Konsep utamnya adalah fungsi, disfungsi, fungsi laten, fungsi manifes dan keseimbangan (equiliberium). Merton mendefinisikan fungsi sebagai konsekuensi konsekuensi yang dapat diamati dan dibuat dengan tujuan adaptasi atau penyesuaian dari sistem tertentu. Adaptasi dan penyesuaian selalu bermakna positif bagi sistem. Pernikahan dini merupakan adaptasi dan penyesuaian untuk menciptakan keteraturan dalam masyarakat. Merton membagi fungsi menjadi 2 bagian yaitu fungsi manifest dan fungsi laten. Fungsi manifes adalah fungsi nyata atau diharapkan, sedangkan fungsi laten adalah fungsi yang tersembunyi dan tidak diharapkan. Dari hasil penelitian ditemukan pernikahan dini yang dilakukan remaja adalah konsekuensi (fungsi) yang diharapkan remaja adalah kebutuhan akan rasa aman, kebutuhan akan cinta dan kasih sayang, dan mengubah kondisi ekonomi keluarga menjadi lebih baik. Namun, dibalik itu semua pernikahan dini yang dilakukan remaja memiliki konsekuensi (fungsi) yang tersembunyi yaitu untuk menutupi aib keluarga dan mencegah timbulnya fitnah. Pernikahan dini yang dilakukan remaja bisa saja tidak lebih dari sebelum mereka menikah. Pernikahan adalah suatu hal yang komplek. Banyak hal yang dibutuhkan seperti kesiapan secara mental, ekonomi dan dukungan penuh kedua keluarga. Apabila 
pernikahan yang dilakukan remaja tersebut justru merusak sistem itulah yang disebut Merton dengan disfungsi.

\section{Kesimpulan}

Berdasarkan hasil temuan penelitian dilapangan dari beberapa informan yang peneliti wawancarai, peneliti menemukan 3 fungsi manifest (yang diharapkan ) remaja melakukan pernikahan dini yaitu kebutuhan akan rasa aman, kebutuhan akan cinta dan kasih sayang secara intens membuat sang remaja ingin melakukan pernikahan dengan harapan kehidupan akan bahagia karena mendapatkan cinta dan kasih sayang dari orang yang ia cintai), dan faktor ekonomi untuk memaksimalkan kebutuhan hidup yang harus dipenuhi agar dapat hidup lebih baik. Serta 2 fungsi laten ( yang tidak diharapkan) yaitu untuk menutupi aib keluarga dan untuk mencegah timbulnya fitnah.

\section{Daftar Pustaka}

Ahmad, F. M. (2016). Ketentuan BATAS Minimal Usia Kawin : Sejarah, Implikasi Penetapan Undang - Undang Perkawinan. 1.

Ani, Y., \& Endah, S. (2019). Perkawinan Bawah Umur Dan Potensi Perceraian ( Studi Kewenangan KUA Wilayah Kota Bogor). 26(1).

Arimurti, I., \& Nurmala, I. (2017). Analisi Pengaruh Perempuan Terhadap Perilaku Melakukan Pernikahan Usia Dini Di Kecamatan Wonosari Kabupaten Bandowoso. 12(12), 249-261.

Bagong, S. (2011). Metode Penelitian Sosial. Prenada Media Grup.

Bugin, B. (2010). Analisis data Penelitian Kualitatif. PT.Raja Grafindo Persada.

Djamilah, \& Reni, K. (2014). Dampak Perkawinan Anak Di Indonesia. 3.

George, R. (2007). Sosiologi Ilmu Pengetahuan Berparadigma Ganda. PT.Raja Grafindo Persada.

Monks, F.J., Knoers, A. M. ., \& S.R, H. (2002). Psikologi Perkembangan: Pengantar dalam Berbagai Bagiannya,. Yogyakarta: Gajah Mada University Press),.

Nurjannah, S., \& Khahijah, Y. F. La. (2018). Pengalaman Wanita Menikah Dini Yang Berakhir Dengan Perceraian. 7(2).

Putri, P. H. (2017). Faktor Yang Berhubungan Dengan Penikahan Usia Dini Terhadap Remaja Putri.

Riska, A., \& Mufdlilah. (2016). Analisis Dampak Perkawinan Dini Terhadap Remaja Putri Di Desa Sidoluhur Kecamatan Godean Yogyakarta.

Robert, L. A., \& B, S. (2002). Marital Quality: A Review of the Seventies. Marriage and Family, 42(4).

Romauli, \& Vindari. (2012). Kesehatan Reproduksi Buat Mahasiswi kebidanan. Nuha Medika.

Santrcok, \& W, J. (2002). Life - Span Develompment (Perkembangan Sepanjang Hidup) (Erlangga (ed.); Erlangga). 2002.

Sugiyono. (2016). Metode Penelitian Pendidikan Pendekatan kuantitatif, Kualitatif dan R\&D. Alfabeta.

Sugiyono. (2009). Metode Penelitian Kualitatif dan Kuantitatif dan R\&D. Alfabeta.

Uswatun, H. (2018). Pengaruh Perkawinan Usia Muda Pada Tingkat Perceraian Dini ( Studi Kasus Pengadilan Agama Kisaran). 